\title{
PELUANG DAN PERUBAHAN CARA BERPIKIR SAAT PANDEMIK (Pengabdian Kepada UMKM Binaan Kadin Provinsi Jawa Barat)
}

\author{
${ }^{1}$ Supardi, ${ }^{2}$ Vincentia Wahju Widajatun, ${ }^{3}$ Nugi Mohamad Nugraha, \\ ${ }^{4 *}$ Neneng Susanti, ${ }^{5}$ Muhammad Bayu Aji Sumantri, ${ }^{6}$ Tanti Irawati Mukhlis \\ Universitas Widyatama \\ Email : $\underline{{ }^{4} \text { neneng.susanti@,widyatama.ac.id }}$
}

Manuskrip: Okt-2020; Ditinjau: Nov -2020; Diterima: Des -2020; Online: Jan-2021; Diterbitkan: Jan-2021

\begin{abstract}
ABSTRAK
Pelatihan teknis subtantif bagi UMKM tahun 2020,tetapi kinerja bisnisnya belum sesuai target yang diharapkan, hal ini diduga berhubungan dengan manajemen usaha, pelatihan menganalisis dan memperoleh temuan kondisi faktual serta menganalisis model agar bisa dijelaskan fenomena dan memprediksi permasalahan manajemen usaha yang optimal dalam menjalankan bisnis dengan memiliki penerapan manajemen usaha yang paling rendah dimiliki oleh pelaku UMKM yaitu dalam penerapan manajemen produksi dan manajemen keuangan pelaku UMKM, akan tetapi pada dimensi metode pelatihan memiliki nilai rendah dalam pelaksanaan pelatihan dirasakan sudah baik terhadap pelaku UMKM hanya dalam penguatan.

Semua usaha di dunia untuk tahun 2020 semua usaha hancur dikarenakan Covid-19 tidak disangka semua harus diberhentikan dan tidak boleh keluar rumah dan berkumpul, tetapi ekonomi harus jalan terus tapi adanya Covid-19 sama dengan musibah bagi orang-orang yang menjadi UMKM harus berhenti jadi petaka untuk tahun 2020 nanti isyaAllah akan menjadi peluang bagi masyarakat khususnya UMKM. Maka tahun 2020 adalah merupakan petaka bagi UMKM 2021 akan menjadi peluang sangat besar bagi usaha mikro kecil dan menengah akan selain ekonomi dan akan menggunakan tenaga kerja yang sangat besar selama tahun 2020 hampir 60\%, pemutusan hubungan kerja (PHK) maka tahun 2021 akan memungkinkan SDM dan ekonomi yang sehat didukung dengan tenaga kerja yang profesional dan mengurangi pengangguran dan merupakan sumber penghasilan bagi masyarakat untuk hidup sehat dan ekonomi tercukupi. Adanya UMKM akan terus meningkat dari usahanya khususnya masyarakat Jawa Barat, meskipun teknologi Cyber dan MEA serta tren revolusi industri 40 sektor usaha mikro kecil dan menengah (UMKM) mudah-mudahan dapat mengubah dalam bidang kehidupan manusia termasuk ekonomi maupun tenaga kerja.
\end{abstract}

Kata Kunci : Mengubah, Petaka, Peluang. 


\section{PENDAHULUAN}

Usaha Kecil Menengah (UKM) sering disebut juga sebagai Usaha Mikro Kecil Menengah (UMKM) merupakan salah satu kekuatan pendorong terdepan dalam pembangunan ekonomi. Gerak Sektor UMKM amat vital untuk menciptakan pertumbuhan ekonomi dan lapangan pekerjaan. Usaha Mikro Kecil Menengah (UMKM) juga cukup fleksibel dan dapat dengan mudah beradaptasi dengan pasang surut permintaan pasar, hal ini dapat dilihat dari UMKM sendiri cukup terdiversifikasi.

Persaingan dunia usaha dan perkembangannya saat ini begitu masih terjadi dengan tingkat persaingan semakin ketat disemua sektor usaha baik mikro, kecil, menengah dan atas. Era Masyarakat Ekonomi ASEAN (MEA) atau ASEAN Economic Community (AEC) yang saat ini sedang dialami oleh para pelaku usaha, menjadi sebuah keharusan bagi setiap pelaku usaha pada setiap sektor untuk terus melakukan upaya perbaikan sebagai bahan evaluasi untuk menuju kearah lebih berkualitas baik produk barang atau jasa yang pada akhirnya akan mampu meningkatkan produktivitas terhadap usahanya. Kondisi tersebut semakin berat bagi pelaku usaha ketika pemerintah pusat mulai mencanangkan konsep revolusi industri 4.0 berbasis internet, tren ini telah mengubah banyak bidang kehidupan manusia, termasuk ekonomi, dunia kerja, bahkan gaya hidup manusia itu sendiri. Singkatnya, revolusi 4.0 menanamkan teknologi cerdas yang dapat terhubung dengan berbagai bidang kehidupan manusia karena pola kerjanya adalah menggabungkan teknologi otomatisasi dengan teknologi cyber (sumber : https://www.maxnanroe.com/revolusi-industri-4-O.html,2019). Menghadapi kondisi usaha demikian, seluruh jenis usaha baik barang maupun jasa dituntut untuk dapat berkembang dan menyesuaikan diri. Salah satu yang harus mendapat perhatian penting di era MEA serta tren revolusi industri 4.0 adalah sektor usaha mikro, kecil dan menengah.

Sektor usaha mikro, kecil dan menengah yang sering disebut UMKM mengalami pertumbuhan yang baik setiap tahunnya dibandingkan dengan sektor usaha besar. Bila dilihat beberapa tahun yang lalu, yaitu selama tahun 2016 - 2017 mengalami perkembangan jumlah UMKM yaitu naik sekitar 1.271.529 pelaku usaha atau 2,06\% dari tahun sebelumnya. Berdasarkan data diatas, UMKM memiliki pengaruh yang besar bagi perekonomian dan pemberdayaan tenaga kerja diIndonesia. Negara-negara dengan sebutan Newly Industrializing Countries (NICs) seperti Korea Selatan, Singapura, dan Taiwan adalah contoh dari negara yang memiliki PDB yang tinggi karena kinerja UMKM mereka yang sangat efisien, produktif, dan memiliki tingkat daya saing global yang tinggi. Begitu pula di Indonesia, UMKM telah mendapatkan perhatian lebih karena pertumbuhannya yang semakin pesat dan merupakan salah satu pelaku ekonomi yang memiliki peran, kedudukan serta potensi yang sangat penting dan strategis dalam mewujudkan pembangunan ekonomi baik secara regional maupun nasional.

Prioritas dalam kebijakan pemerintah saat ini difokuskan pada sektor UMKM, hal ini disebabkan karena sektor UMKM memiliki peran penting dalam pertumbuhan perekonomian Indonesia, terbukti mereka menyumbangkan 60,6\% 
produk domestic bruto setiap tahunnya serta berperan besar dalam menyerap tenaga kerja sebesar 107,6 juta penduduk di Indonesia (kompas.com, 2018).

Pengertian UMKM di Indonesia sering dipahami dengan sudut pandang yang berbeda berdasarkan pengklasifikasian menurut berbagai instansi Pemerintah. Menurut Departemen Perindustrian, Usaha Kecil Menengah (UKM)didefinisikan sebagai Perusahaan yang dimiliki oleh Warga Negara Indonesia ), memiliki total asset tidak lebih dari Rp 600 juta (diluar area perumahan dan perkebunan). Sedangkan menurut Biro Pusat Statistik (BPS), defenisi UKM lebih mengacu kepada klasifikasi skala usaha dan jumlah tenaga kerja yang diserap yang menggunakan skala kecil kurang dari 5 (lima) orang karyawan_atau usaha menengah yang menyerap tenaga kerja antara 5 (lima) hingga 19 (sembilan belas) orang. Diperkirakan UMKM akan tumbuh lebih cepat setelah krisis ekonomi, tetapi seringkali Usaha Mikro Kecil Menengah (UMKM) mengalami pasang surut dan taksedikit yang mengalami hambatan dan akhirnya sulit untuk berkembang.

Permasalahan yang paling sering timbul dalam pengembangan Usaha Kecil Menengah (UMKM) berhubungan dengan karakteristik yang dimiliki olehusaha kecil ini sendiri. (Lupioyadi, 2007: 5)

UMKM telah menjadi tulang punggung perekonomian Indonesia dan ASEAN. Sekitar 88,8-99,9\% bentuk usaha di ASEAN adalah UMKM dengan penyerapan tenaga kerja mencapai 51,7-97,2\%. (http:/hvww.lisubisnis.com/2016) oleh karena itu, kerjasama untuk pengembangan dan ketahanan UMKM diutamakan. Perkembangan potensi UMKM di Indonesia.

Namun, pada kenyataannya masih terdapat banyak tantangan yang harus dihadapi oleh para pelaku usaha disektor UMKM. Maka dari itu, Pemerintah Provinsi Jawa Barat melalui Dinas Koperasi dan Usaha Kecil UPTD Balai Pendidikan dan Pelatihan Perkoperasian dan Wirausaha (BP3W) telah melakukan upaya untuk terus membina para pelaku usaha UMKM di Provinsi Jawa Barat. Salah satunya dengan program pendampingan UMKM. Dalam melaksanakan program tersebut, BP3W Provinsi Jawa Barat menggunakan 29 orang tenaga pendampinng yang tersebar di 27 KabupatenKota se-Jawa Barat dengan jumlah kurang lebih 1.450 UMKM.

Usaha Mikro Kecil dan Menengah (UMKM) diharapkan memiliki daya saing sehingga memiliki kinerja bisnis yang baik serta bisa tumbuh dan berkembang. Pada akhirnya, dapat membuka lapangan pekerjaan. Inilah kontribusi wirausaha kepada pemerintah untuk mengurangi pengangguran di masyarakat.

Dengan peranan UMKMyang sangat penting, maka sebetulnya UMKMmerupakan sektor ekonomi yang tidak hanya memberikan kegiatan usaha pada rakyat kecil saja, namun juga dapat berperan sebagai alternatif pemecahan masalah sosial seperti ledakan jumlah tenaga kerja yang terus bertambah di Indonesia. Peranan-peranan penting inilah yang menjadikan alasan agar UMKM tetap dikembangkan di Indonesia, khususnya di Jawa Barat. Pengalaman menunjukan bahwa usaha mikro kecil dan menengah (UMKM) memiliki ketangguhan terhadap goncangan ekonomi global. 
Disamping itu usaha mikro kecil dan menengah juga memiliki kemampuan menyerap tenaga kerja yang besar, membuka peluang usaha baru dan dapat mewujudkan peningkatan dan pemerataan pendapatan masyarakat. Dengan landasan UMKM yang kuat maka struktur ekonomi akan menjadi kokoh, yang mempunyai peranan penting bagi Indonesia menurut (Febrianti) UMKM merupakan usaha di Indonesia tetapi sektor UMKM tetap eksis.

Peran terutama dalam penciptaan lapangan pekerjaan dan pembentukan PDRB Jawa Barat. PDRB Jawa Barat yang mencapai Rp 231.764 milyar menyumbang $14-15$ persen dari total PDB nasional, angka tertinggi bagi sebuah provinsi. Mengingat jumlah penduduk yang besar, PDB per kapita Jawa Barat adalah Rp 5.476.034 termasuk minyak dan gas, ini menggambarkan 82,4 persen dan 86,1 persen dari rata-rata nasional. Pertumbuhan ekonomi berkisar 4,21 persen tidak termasuk minyak dan gas dan 4,91 persen termasuk minyak dan gas, angka pertumbuhan ini lebih baik dari Indonesia secara keseluruhan (diskumkm.jabarprov.go.id). Jumlah UMKM yang terdapat di Jawa Barat menurut Badan Pusat Statistik mencapai 8.214.262 unit dengan jumIah sentra UMKM di Jawa Barat mencapai 138 sentra yang tersebar secara spasial di lima wilayah yakni Cirebon, Bogor, Priangan Timur dan Barat, dan Purwakarta. Sebaran hampir merata dengan sedikit terkonsentrasi di wilayah Priangan Timur dan Bogor.

Kontribusi PDB Provinsi Jawa Barat terhadap PDB Nasional yaitu, tahun 2008 kontribusi PDB Jawa Barat sebesar 14,56\%, tahun 2009 kontribusi PDB Jawa Barat sebesar 14,49\% dan tahun 2010 kontribusi PDB Jawa Barat sebesar 14,49\%. Hal ini memperlihatkan Provinsi Jawa Barat memitiki beberapa keunggulan antara lain, sebagai pusat kegiatan ekonomi, memiliki infrastruktur lebih baik, memiliki tenaga kerja terampil dan mudahnya akses pasar dalam negeri dan internasional bagi produk yang dihasilkan. Salah satu upaya untuk menciptakan UMKM tangguh adalah melalui pemberdayaan UMKM yang ada dengan melakuan pembinaan pada manajeman usaha, pelatihan serta dilakukan pendampingan usaha. Sebab dengan dilakukannya hal-hal tersebut di atas akan mampu membuat para pelaku usaha bisa untuk menghadapi persaingan global saat ini di tengah bergulirnya MEA (Masyarakat Ekonomi Asia). Dengan adanya MEA sangat dikhawatirkan keberadaan para pelaku usaha jika tidak dalam keadaan yang siap menghadapi persaingan tersebut.

\section{METODE PELAKSANAAN KEGIATAN}

Pelatihan lewat zoom dalam pengabdian kepada masyarakat dengan menggunakan metode zoom / geogle meet dan materi disebarkan lewat zoom dan akan dipraktikkan melalui media zoom com selain ceramah dan penyuluhan materi kepada peserta juga diberikan kesempatan tanya jawab seperti di ruangan metode 
ini sangat efesien dan singkat dan jelas dan terakhir diberikan sertifikasi sebagai tanda peserta pelatihan dan kepada Kepala KADIN ikut respon memberikan ceramah di zoom dan para UMKM saling meminta masang UMKM usahanya dan minta alamat serta tukar pengalaman

\section{HASIL DAN PEMBAHASAN}

Berdasarkan hasil kegiatan UMKM yang diselenggatakan melalui zoom darijumlahundangansebanyak 20 UMKM yang terdaftar tetapi yang hadir mengikuti zoom 12 peserta dan ditambah dengan Kepala Kadin Jabar dan Dosen Widyatama tetapi belum memenuhi target $100 \%$ jika dibandingkan dengan jumlah UMKM dari pengikuti zoom yang mengikut dapat dikatagorikan berhasil atau sukses, untuk tercapainya tujuan pelatihan. Maka dari UMKM Jawa Barat yang memiliki fungsi sebagai pengawas dan University Widyatama sebagai penyelenggara dan koordinasi pelalihan UMKM yang memiliki visi terwujudnya.

Sumber daya manusia (SDM) dan usaha kecil yang kompeten produktif, proposional dan berdaya saing pada era globalisasi yang diharapkan akan mampu membuatkan pelayanan yang baik kepada pelaku UMKM Jawa Barat yang melalui kegiatan pelatihan-pelatihan kepada para pelaku usaha dan salah satunya adalah kegiatan non fisik untuk meningkatkan UMKM.

Misi mewujudkan visi tersebut diatas dan ditunjang oleh beberapa misi strategis yang dilakukan Kadin Propinsi Jawa Barat sebagai berikut :

- Menyelenggarakan pelatihan tenaga UMKM

- Mengembangkan program pelatihan

- Meningkatkan SDM dan wirausaha

- Meningkatkan sinergitas praktisi akademik, birokrasi, komunitas.

Dengan demikian karena adanyaCovid 19 maka pelatihan tidak usah tatap muka cukup dengan melalui zoom maupun google com tidak mengurangi semangat mencari pengalaman dan kerjasama untuk mencari keuntungan laba/profit.hasil penelitian pada Joko Setyono (2018) dimana hasil menunjukan hasil pelatihan UMKM manajer usaha berpengaruh signifikan terhadap pendapatan yang didukung oleh penelitian yang dilakukan Susi Herin (2014) dimana hasil menunjukkan bahwa pelatihan mempunyai pengaruh positif terhadap penghasilan para pelaku usaha makanan dan minuman danadanyaperbedaanantarasebelumdansesudah pelatihan penghasilan dari profil / laba usaha UMKM. Dan pelatihan ini sudah ada dampak positif yang sudah saya lihat adanya UMKM lebih jelas tentang teknologi dalam kegiatan ini, masalah ekonomi dan usahanya dengan meningkat pemahaman UMKM terhadap e-businis menjadi hati-hati dan waspada setiap penjualan dari usaha yang berhubungan dengan penjualan harus mampu memanfaatkan celahcelah penjualan dengan kredit atau angsuran dan kredit dari bank untuk angsurannya harus jelas disesuaikan dengan profit atau penghasilan dari usaha jangan sampai tidak mampu pembayarannya setiaphariataubulannya.

Semangatdari para peserta dirasakan pula dari beberapa pertanyaan yang diajukan oleh para peserta yaitu: 
- Dari Bapak Irvan yang memproduksi bumbu dengan bermacam varian menanyakan tentang system ERP yang tepat dan sesuai dengan kondisi keuangan bagi UMKM.

- Dari Ibu Henny yang memproduksibermacam snack mengalami kesulitan untuk menjual produknya saat pandemic karena took - toko yang biasa tempat menjual produknya tutup sehingga banyak produk yang diretur menyebabkan menumpuknya stok barang.

Adapun masukkan untuk pertanyaan tersebut merupakan hasil diskusi selama pelaksanaan PKM menggunakan Zoom yaitu untuk system ERP bagi UMKM belum dibutuhkan system yang khusus sehingga penggunaan aplikasis epertims office atau aplikasi yang sekarang banyak di play store masih bisa digunakan. Yang dibutuhkan adalah konsistensi dan ketelitian dalam pencatatan. Sedangkan solusi untuk penumpukan stock adalah menjual melalui online, dengan memanfaatkan jaringan yang dimiliki oleh UMKM atau mencoba mempromosikan dengan menitipkan gambar melalui akun dari rekan atau kerabat yang memiliki follower cukup banyak.

Dengan demikian kemungkinan pertemuan antara penjual dan pembeli meningkat. Atau dengan kata lain UMKM mempersiapkan diri untuk pemasaran digital.

\section{KESIMPULAN DAN SARAN}

Berdasarkan kuesioner PKM bahwa UMKM ada permasalahan atau kendala pada keuntungan atau finansial dan pemasaran maupun penjualan apa lagi sekarang akibat pandemik, meskipun pemasaran lewat online juga memberikan tekanan kepada semua usaha baik secara besar mapun kecil termasuk usaha makro, kecil dan menengah (UMKM) maka harus merubah strategi bagaimana cara pemasaran dan merubah bagaimanna penjualan kepada konsumen yang lebih baik dan efisien karena tenaga kerjanya kebanyakan dirumahkan (PHK) hampir seluruh UMKM penjualan menurun drastis pada tahun 2020 apabila kita mendapatkan bahan baku dari impor dari negara-negara yang mempunyai bahan baku sulit sekali, jadi dari penjualan barang kurang laku dari produksi susah bahan baku impor dari Dwi Aditya (liputan 6. Com/03 Juni 2020) UMKM mencari pengganti bahan baku yang ada di Indonesia atau subsitusipun juga mengalami langka.

Perubahan cara berpikir dari UMKM merupakan hal penting dalam bertahan saat pandemic, salah satunya mengubah bentuk pemasaran yang biasanya dilakukan melalui toko-toko offline, menambah tokonya dalam bentuk online, untuk awalnya masih bisa berupa bentuk promosi melalui social media yang dimiliki oleh UMKM atau menitipkan informasi mengenai produk pada social media milik rekan atau kerabat. Penggunaan aplikasi yang ada saat ini untuk membenahi pencatatan dan penjualan bagi UMKM.

UMKM sangat membantu kepada pemerintah dalam hal menciptakan lapangan diberbagai usaha kerja yang baru diberbagai unit-unit usaha baru yang 
menggunakan tenaga kerja yang baru untuk mendapatkan penghasilan rumah tangga salah satunya tulang punggung dalam perekonomian Indonesia

\section{DAFTAR PUSTAKA}

Affandi, A., Sarwani, ., Sobarna, . A., Erlangga, . H., Siagian, . A. O., Purwanto, . A., Effendy, . A. A., Sunarsi, . D., Wicaksono, . W., Suyatin, ., Ariyanti, . E., Wahyitno, ., Manik, . C. D., Juhaeri, . \& Gunartin, . (2020) Optimization of MSMEs Empowerment in Facing Competition in the Global Market during the COVID-19 Pandemic Time. Systematic Reviews in Pharmacy, 11 (11), 1506-1515. doi:10.31838/srp.2020.11.213

Febrianti ; UMKM Merupakan Usaha di Indonesia Tetapi Sektor UMKM Tetap Eksis.

Joko Setyono ; 2018 ; UMKM Terhadap Hasil Penghasilan

Khoiri, A., Sobarna, . A., Sarwani, ., Siagian, . A. O., S, . R. Y., Kusworo, ., Surasni, ., Rahmanita, . F., Gunartin, ., Hidayati, . S., Purwanto, . A., Faroh, . W. N., Masadi, . M., Sunarsi, . D. \& Teriyan, . A. (2020) An Overview: Inquiry Based Science Learning Models in Empowering Creative Thinking Skills High School Student. Systematic Reviews in Pharmacy, 11 (11), 1466-1476. doi:10.31838/srp.2020.11.207

Lupio ; $2007: 5$; Pengembangan UMKM Dengan Karakteristik UMKM

Mochsiono ; 2014; Pengukuran Kinerja Kompetensi ; M Raja 6 ; Rrefindo Pustaka

Paeno, P., Kasmad, K., Sunarsi, D., Maddinsyah, A., \& Supiyan, D. (2020). Pemanfaatan Sampah Plastik Untuk Kerajinan Rumah Tangga Taman Belajar Kreatif Mekar Sari. Baktimas: Jurnal Pengabdian pada Masyarakat, 2(1), 57-61.

Rahab, Sulisttyandari Dan Sudjono; 2011; Doi Capability Ofsme Trough Knowledge Proses And An Empirical And Social.

Sunarsi, D., Kustini, E., Lutfi, A. M., Fauzi, R. D., \& Noryani, N. (2019).

Penyuluhan Wirausaha Home Industry Untuk Meningkatkan Ekonomi

Keluarga Dengan Daur Ulang Barang Bekas. Baktimas: Jurnal

Pengabdian pada Masyarakat, 1(4), 188-193.

Tambunan, Tullur; 2012; UMKM isu penting LP3ES Jakarta.

www.jurnal.id/bdg/2018

www.depkop. go.id/bee informasi data informasi tahun (2016).

www.maxmanroe. comrevolusi-industri 4.0 hal 2019

www.tekno.kompas com; 2018

diskom jabar prov go.id. 